Article

\title{
The Spatial Distribution, Contamination Status and Contributing Factors of Heavy Metals in Cropland Soils of Twelve Cities in Shandong Province, China
}

\author{
Weina Xue ${ }^{1,2}$, Yanbo Peng ${ }^{3}$, Aixia Jiang ${ }^{1}$, Taiyu Chen ${ }^{2}$ and Jiemin Cheng ${ }^{1, *}$ \\ 1 College of Geography and Environmental Science, Shandong Normal University, Jinan 250300, \\ China; qingjeep@163.com (W.X.); 110051@sdnu.edu.cn (A.J.) \\ 2 School of Municipal and Environmental Engineering, Shandong Jianzhu University, Jinan 250101, \\ China; cty0826289@163.com \\ 3 Shandong Academy for Environment Planning, Jinan 250101, China; pengyanbo@sdaep.com \\ * Correspondence: 110087@sdnu.edu.cn; Tel.: +86-0531-86181939
}

Received: 8 February 2020; Accepted: 6 March 2020; Published: 13 March 2020

\begin{abstract}
The aims of this study were to analyze the spatial distributions of, contamination statuses of, and factors contributing to, heavy metals in cropland areas of different cities; thus, 55 agricultural soils were collected from 12 cities of Shandong Province, China. Concentrations of copper $(\mathrm{Cu})$, lead $(\mathrm{Pb})$, cadmium $(\mathrm{Cd})$, chromium $(\mathrm{Cr})$, nickel $(\mathrm{Ni})$ and zinc $(\mathrm{Zn})$ were determined. Results showed that average contents of $\mathrm{Cu}, \mathrm{Pb}, \mathrm{Cd}, \mathrm{Cr}$, Ni and $\mathrm{Zn}$ were 24.13, 31.77, 0.16, 130.63, 22.13, and 71.19 $\mathrm{mg} \cdot \mathrm{kg}^{-1}$, respectively, and $\mathrm{Pb}$ and $\mathrm{Cd}$ had similar spatial distributions in those cities. Specifically, contents of $\mathrm{Cr}$ in cities of Weifang, Weihai, Yantai and Zibo were significantly higher than it in other cities; Weihai and Zibo also had significantly high contents of $\mathrm{Zn}$. Moreover, concentrations of $\mathrm{Cr}$ in brown soils and cinnamon soils were significantly higher than that in fluvo-aquic soils, while other metals showed no significant differences among the soil types. Furthermore, $\mathrm{Cu}, \mathrm{Pb}$ and $\mathrm{Zn}$ showed significant concentration decreases with respect to those measured in 2007. The correlation analysis and factor analysis indicated that the contamination of $\mathrm{Pb}$ and $\mathrm{Cd}$ was mainly caused by economic activities. In addition, the significantly correlated $\mathrm{Cu} / \mathrm{Ni} / \mathrm{Zn}$ and $\mathrm{Pb} / \mathrm{Cd}$ indicated the inputs from different human activities, while $\mathrm{Cr}$ was prone to multiple sources. This study demonstrated that more attention should be given to the contamination by $\mathrm{Cr}, \mathrm{Pb}$ and $\mathrm{Cd}$, and that the management of human economic activities is vitally imperative for safety of surrounding cropland soils.
\end{abstract}

Keywords: cropland soils; industrial added value; metal accumulation; soil types

\section{Introduction}

Soil is a fundamental component of ecosystems and is involved in various human activities, among which, food production is an important function for the survival of mankind [1,2]. However, industrial production and other producing activities usually discharge plenty of pollutants, which would pollute the surrounding cropland [3]. Owing to the rapid industrial and agricultural development, the accumulation of pollutants in agricultural soils in China has become increasingly serious $[4,5]$.

Since the Chinese reform and opening up, economic development in the countryside has greatly increased by governmental effective measures, such as transferring industries from urban areas to the countryside, improving planting technology, increasing employment, etc. [6]. Meanwhile, large quantities of wastewater and pollutants are discharged into surrounding soils and wetlands due to the lack of pollution management and controls in China $[7,8]$. Industrial sewage, domestic wastewater and agrochemicals contain a great deal of heavy metals, which have the 
characteristics of toxicity, abundance and persistence [4,9]. Thus, heavy metal contamination in soils has become a serious problem in China, and even in the world [10]. Heavy metals can be bio-accumulated into vegetation and absorbed by the contactee, and then transferred into human bodies directly or indirectly [11]. Therefore, metal contamination in agricultural soils has threatened human health and should be given more attention [11].

In recent years, cropland soils in many areas of China have been suffering from the contamination of chromium $(\mathrm{Cr})$, copper $(\mathrm{Cu})$, lead $(\mathrm{Pb})$, zinc $(\mathrm{Zn})$, nickel $(\mathrm{Ni})$ and cadmium $(\mathrm{Cd})[5,12,13]$. For example, $\mathrm{Cd}$ and $\mathrm{Pb}$ were excessively enriched in cropland soils near the Pearl River Delta, South China [12]. Previous reports showed that distribution and accumulation of heavy metals in agricultural soils of Shunyi, Beijing, Shanghai, Huizhou and many other cities significantly differed [12-16]. However, there are few studies concentrated on the spatial distribution patterns of heavy metals in the agricultural soils of different cities in the same province systematically, which can present the accumulating difference and similarity and contamination status of heavy metals in the areas, and can also provide data references for relevant research to explore the macro trends of metal accumulation among the provinces, China and even the world. Then, municipal management and control measures can be implemented based on the pollution status.

Due to different climates, humidity, etc., the world contains many different soil types, which can hold different contents of heavy metals [17]. For example, yellow brown soil and cinnamon soil show different contents and absorption of $\mathrm{Cu}, \mathrm{Pb}$ and $\mathrm{Cd}$ [18]. Thus, soil types may be an important factor affecting the spatial features of heavy metals, but are rarely studied up to now. Moreover, previous studies indicated that anthropogenic activities most resulted in the metal contamination in cropland soils [12,13]. For example, industrial and agronomic practices, industrial fume, coal burning exhausts and domestic waste reportedly led to various degrees of heavy metal accumulation to the local cropland soils in Northeast China [19], Gan et al. (2019) suggested that human activities contribute $65.8 \%-86.0 \%$ to the metal accumulation in surrounding farmland soils [20]. It is unclear whether human activities can lead to large areas of agricultural soil pollution or not. Economic production dominates the effects of human activities on metal contamination in soils $[12,20,21]$; thus, the exploration on economic producing and metal contents may indicate their correlations.

Shandong Province is situated in the eastern coast of China. Its total area is 155,800 square kilometers, and the total soil area is 121,100 square kilometers. It has a population of over 100.47 million and governs 16 cities (Figure 1). The topography of Shandong Province is complex and diverse; its eastern area belongs to the Shandong peninsula, the western and northern areas are parts of the North China Plain, and the southern area has various mountains [22]. The Yellow River, Haihe River, Huaihe River and many tributaries are the dominant rivers that flow through Shandong Province from the east to the west and finally discharge into coastal zones. In addition, brown soils, cinnamon soils and fluvo-aquic soils are three dominant soil types which account for $14.09 \%, 14.66 \%$ and $38.53 \%$ of the soil areas in Shandong Province, respectively [23,24]. The cultivated rate and agricultural added value in Shandong Province ranked first in China, among which, corn and wheat are the main crops. The gross value of the production of Shandong Province was 7647.0 billion in 2017, $43.99 \%$ of which was the added value of secondary industry. Therefore, Shandong Province is a big province for industry and agriculture, which provides an ideal research area to study the spatial distributions and contamination statuses of heavy metals in cropland soils of different cities, and the contributing factors. In addition, the metal accumulation in cropland soils from 2007 to 2017 can also be compared to analyze the metal changes during the decade [5]. 


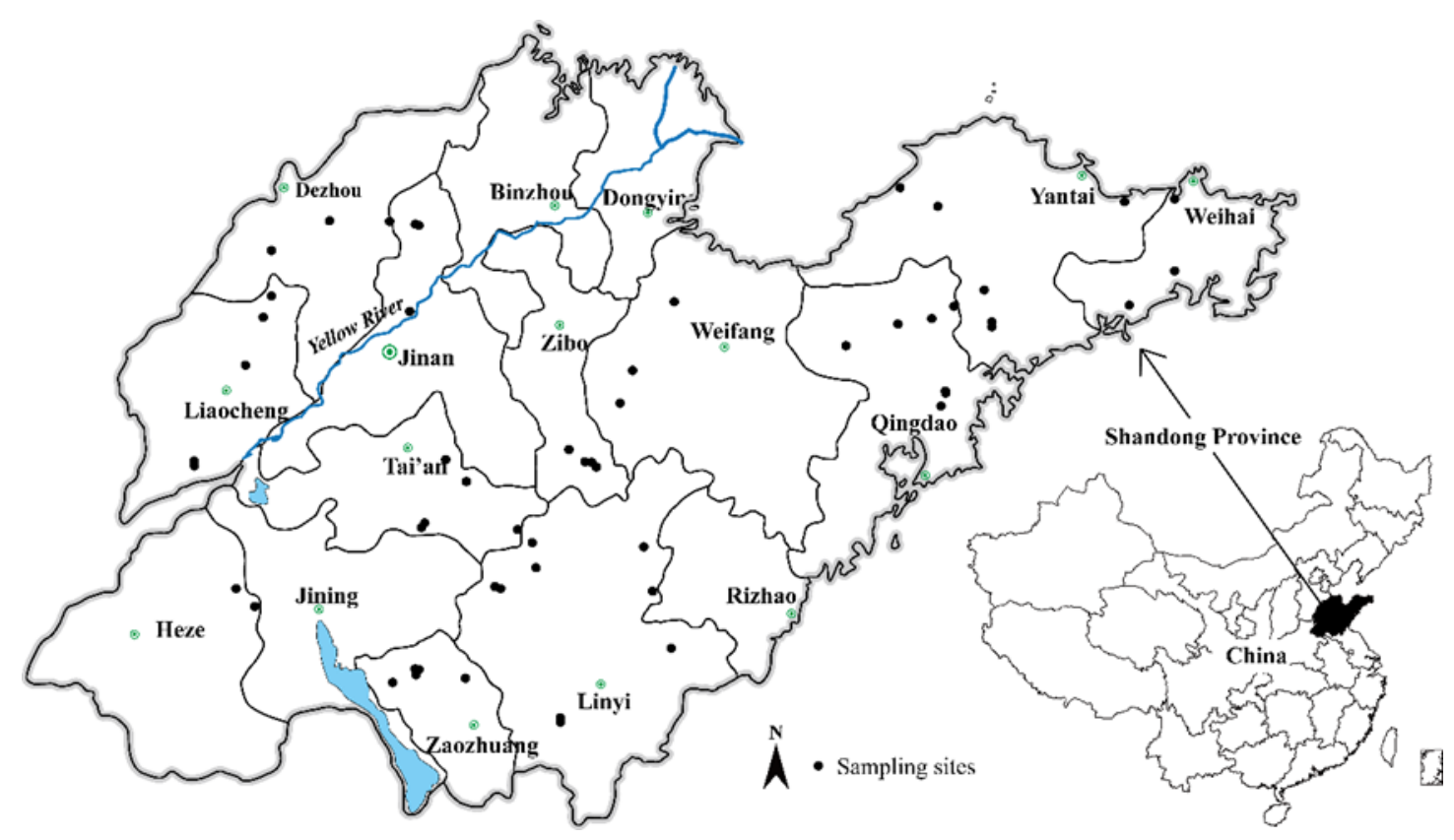

Figure 1. The location of sampling sites in the twelve cities of Shandong Province.

Thus, the primary objectives of this study are: (1) to determine spatial variance and contamination status of heavy metals in agricultural soils in cities of Shandong Province, China; (2) to analyze the impacts of soil types on the metal accumulation; (3) to explore the heavy metal changes from 2007 to 2017 and the possible industrial sources to metal contamination. We believe the study on cropland soils of Shandong Province could provide essential information for relevant research.

\section{Materials and Methods}

\subsection{Study Area}

Shandong Province has a warm, temperate monsoon climate, and sufficient light resources, with a hot and a rainy season. The precipitation and light is mainly concentrated in summer, and the average annual precipitation is $550-950 \mathrm{~mm}$, decreasing from southeast to northwest. The annual average temperature is $11-14{ }^{\circ} \mathrm{C}$. The average frost-free period is 180 days in northern and eastern areas, and 220 days in the southwest of Shandong Province. Shandong Province has high grain yield, and wheat and corn are grown in summer and autumn, respectively.

\subsection{Soil Sampling}

Among the 16 cities in Shandong Province, 55 soil samples from cropland soils of Qingdao, Weihai, Yantai, Linyi, Tai'an, Zaozhuang, Weifang, Zibo, Heze, Liaocheng, Dezhou and Jinan were collected in December, 2017 in this study (Figure 1). Surface soils in each site were collected into sealed bags by five-point sampling method in $1 \mathrm{~m}^{2}$. The specific sampling sites were the same with the study sites of Zhang et al., and the specific longitude and latitude were listed in Table S1 [5]. In addition, the primary soil types and background values of certain heavy metals in the 16 cities of Shandong Province were listed in Table 1. 
Table 1. The background values of the metals in different cities of Shandong Province $\left(\mathrm{mg}^{\mathrm{k}} \mathrm{kg}{ }^{-1}\right)$.

\begin{tabular}{|c|c|c|c|c|c|c|c|}
\hline $\begin{array}{c}\text { Soil } \\
\text { Types }\end{array}$ & $\mathrm{Cu}$ & $\mathrm{Pb}$ & $\mathrm{Cd}$ & $\mathrm{Cr}$ & $\mathbf{N i}$ & $\mathrm{Zn}$ & Related Cities \\
\hline $\begin{array}{c}\text { Brown } \\
\text { soil }\end{array}$ & 22.4 & 25.1 & 0.092 & 64.5 & 26.5 & 68.5 & $\begin{array}{c}\text { Qingdao, Weihai, } \\
\text { Yantai, Dongying } \\
\text { Linyi, Tai'an, }\end{array}$ \\
\hline $\begin{array}{l}\text { Cinnamon } \\
\text { soil }\end{array}$ & 24.3 & 21.3 & 0.1 & 64.8 & 30.7 & 74.1 & $\begin{array}{c}\text { Zaozhuang, } \\
\text { Weifang, Zibo, } \\
\text { Rizhao, Binzhou }\end{array}$ \\
\hline $\begin{array}{l}\text { Fluvo-aquic } \\
\text { soil }\end{array}$ & 22.1 & 21.9 & 0.103 & 66.6 & 29.6 & 71.1 & $\begin{array}{c}\text { Heze, Liaocheng, } \\
\text { Dezhou, Jinan, } \\
\text { Jining }\end{array}$ \\
\hline
\end{tabular}

\subsection{Soil Analysis}

After air-drying at $20^{\circ} \mathrm{C}$, soil samples were ground and then sifted through a 2-mm nylon sieve to get rid of plant debris and gravels. Then, soils were sifted through a 0.149-mm nylon sieve to obtain fine particles. After weighing $0.2000 \mathrm{~g}$ soil samples by electronic balance, they were transferred into polytetrafluoroethylene crucibles. Then, crucibles were placed on the electric platen for digestion. With the addition of $10 \mathrm{~mL}$ of $\mathrm{HNO}_{3}, 5 \mathrm{~mL}$ of $\mathrm{HF}$ and $2 \mathrm{~mL}$ of $\mathrm{HClO}_{4}$, soils were heated in $130{ }^{\circ} \mathrm{C}$ for $12 \mathrm{~h}$. Then, we continued heating in $180{ }^{\circ} \mathrm{C}$ till the residues in crucibles were less than $1 \mathrm{~mL}$, and residues ware collected by dissolving in $1 \mathrm{~mL} \mathrm{HNO}_{3}(50 \%)$ and transferred into volumetric flasks, with $25 \mathrm{~mL}$ ultrapure water [25]. The solutions were filtered into glass tubes and stored at $4{ }^{\circ} \mathrm{C}$.

The elements of $\mathrm{Cr}, \mathrm{Cu}$ and $\mathrm{Zn}$ were examined by inductively coupled plasma atomic emission spectrometry (ICP-AES; IRIS Advantage OPTIMA 7000DV, Thermo Fisher Scientific Incorporated Company, Shanghai, China). Graphite furnace atomic absorption spectrometry (AANALYST800, Perkin Elmer Limited Company, Waltham, MA, USA) was used to determine $\mathrm{Cd}$ and $\mathrm{Pb}$. For $\mathrm{pH}$, about $10 \mathrm{~g}$ of soils and $25 \mathrm{~mL}$ distilled water were mixed, stirred, left for $4 \mathrm{~h}$ and determined by the $\mathrm{pH}$ meter (Rex PHS-3E, Shanghai INESE Scientific Instrument Limited Company, Shanghai, China).

\subsection{Statistical Analysis}

Gross product, industrial and agricultural added values of the studied cities were searched from cities' yearbooks; the websites are displayed in Tables S2 and S3. Concentrations of heavy metals were statistical analyzed by using the SPSS (version 21.0, IBM Company, New York, NY, USA, 2012). Essentially, the means, standard errors, and the maximum and minimum values of heavy metals were calculated. For the factors of different cities, soil types and economic indicators, one factor analysis of variance, Pearson correlation analysis and cluster analysis were conducted. We used a Duncan test for post hoc multiple comparisons. The spatial distribution of the sampling sites was generated by using ArcGIS (version 10.2, Environmental Systems Research Institute Incorporated Company, Redlands, CA, USA, 2014) and Adobe Illustrator (version CS6, Adobe Systems Incorporated Company, San Jose, CA, USA, 2012).

\section{Results and Discussion}

\subsection{The Spatial Distribution Patterns of Heavy Metals in the Twelve Cities}

The average values of $\mathrm{Cu}, \mathrm{Pb}, \mathrm{Cd}, \mathrm{Cr}, \mathrm{Ni}$ and $\mathrm{Zn}$ were 24.13, 31.77, 0.16, 130.63, 22.13 and $71.19 \mathrm{mg} \cdot \mathrm{kg}^{-1}$, respectively, suggesting that most cropland soils were suffering from the contamination of $\mathrm{Cr}, \mathrm{Pb}$ and $\mathrm{Cd}$. Concentrations of $\mathrm{Cr}$ ranged from 31.2 to $335.0 \mathrm{mg} \cdot \mathrm{kg}^{-1}$; that indicated the significantly high spatial disparity in these cities. Contents of $\mathrm{Cr}$ in Liaocheng and Dezhou were below the background value, and significantly lower than that in other cities (Figure 2). Moreover, cluster analysis of $\mathrm{Cr}$ among the twelves cities showed that three coastal cities (Weifang, Weihai and Yantai) and one inland city (Zibo) were gathered into one cluster, with the significantly high concentrations of 
$181.13,177.8,161.62$ and $172.78 \mathrm{mg} \cdot \mathrm{kg}^{-1}$, respectively (Figures 2 and 3). Similarly, the gross values of industrial output of Weifang, Yantai and Zibo were 230.75, 330.94 and 218.31 billon in 2017, which were also significantly higher than other cities, except Qingdao (tourism dominated the gross product). The higher accumulation of $\mathrm{Cr}$ and higher gross value of industrial output in these cities than in other cities may indicate that industrial producing can aggravate the accumulation of $\mathrm{Cr}$ in the agricultural soils, and the specific relations need further research. Both Albanese et al. [26] and Lei et al. [27] showed that certain metals can migrate from the inland to the coast, especially $\mathrm{Cr}$ and $\mathrm{Ni}$, and in the areas along the flowing rivers. They showed that concentrations of $\mathrm{Cr}$ was gradually higher from inland to coast in this study, while the spatial distribution of Ni was not significant (Figure 2). This trend of $\mathrm{Cr}$ in this study may attribute to the impact of water flows and the high mobility of $\mathrm{Cr}$ [28].

With a slight fluctuation from 8.1 to $40.6 \mathrm{mg} \cdot \mathrm{kg}^{-1}$, average concentrations of $\mathrm{Ni}$ were lower than the background values, indicating the relatively low and stable accumulation of $\mathrm{Ni}$ in agricultural soils of the studied cities. Though the contents of $\mathrm{Ni}$ in Zibo and Heze (28.65 and $27.8 \mathrm{mg} \cdot \mathrm{kg}^{-1}$ ) were approaching the background values, the contamination of $\mathrm{Ni}$ was the slightest compared to other metals. Previous reports showed that the contamination of Ni is not serious in cropland, which may attribute to the relative scarcity of $\mathrm{Ni}$ in China and the low human input $[29,30]$. The content of $\mathrm{Cu}$ in Weihai $\left(42.87 \mathrm{mg} \cdot \mathrm{kg}^{-1}\right)$ was significantly higher than in other cities, and was followed by that in Zibo $\left(33.98 \mathrm{mg} \cdot \mathrm{kg}^{-1}\right)$, suggesting that agricultural soils in the two cities faced high input of $\mathrm{Cu}$. It was deduced that the primary input of $\mathrm{Cu}$ was from the industrial activities, as Weihai and Zibo are cities of heavy industry [31,32]. In addition, contents of $\mathrm{Cu}$ in Heze and Zaozhuang also exceeded the background values. The mean concentration of $\mathrm{Zn}$ was $71.19 \mathrm{mg} \cdot \mathrm{kg}^{-1}$, and half of the cities showed higher contents of $\mathrm{Zn}$ than the background value. Moreover, Weihai and Zibo showed significantly higher accumulation of $\mathrm{Zn}$ than other cities, which was similar with the spatial distribution of $\mathrm{Cu}$. The finding further indicated that $\mathrm{Zn}$ and $\mathrm{Cu}$ had similar industrial input [31].

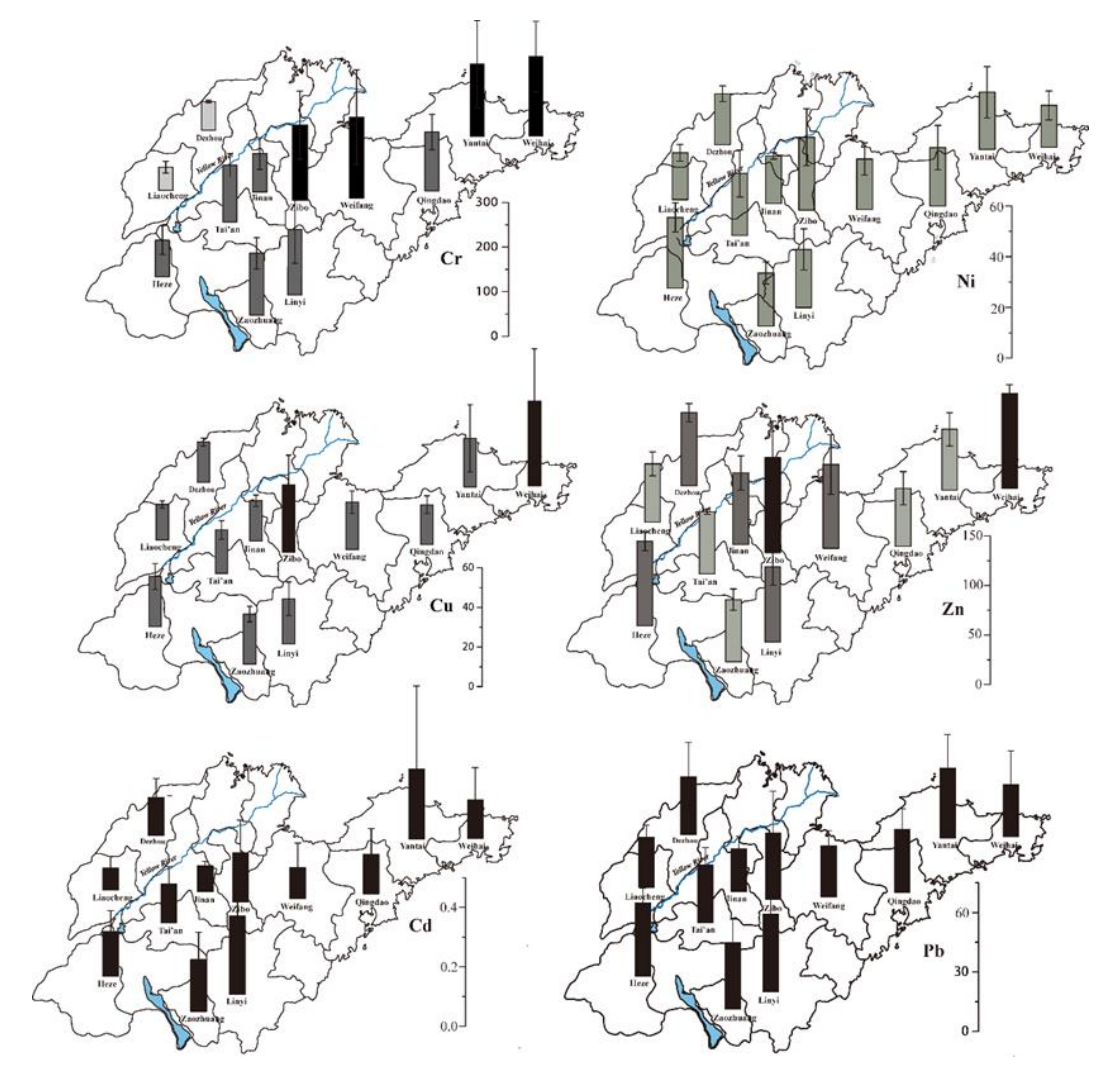

Figure 2. The spatial distribution patterns and concentrations of heavy metals in cropland soils of the cities in Shandong Province. Bars sharing the same color of each metal are not significant at $\alpha=0.05$ (Duncan test). 
The dendrogram based on the mean Euclidean distance between groups

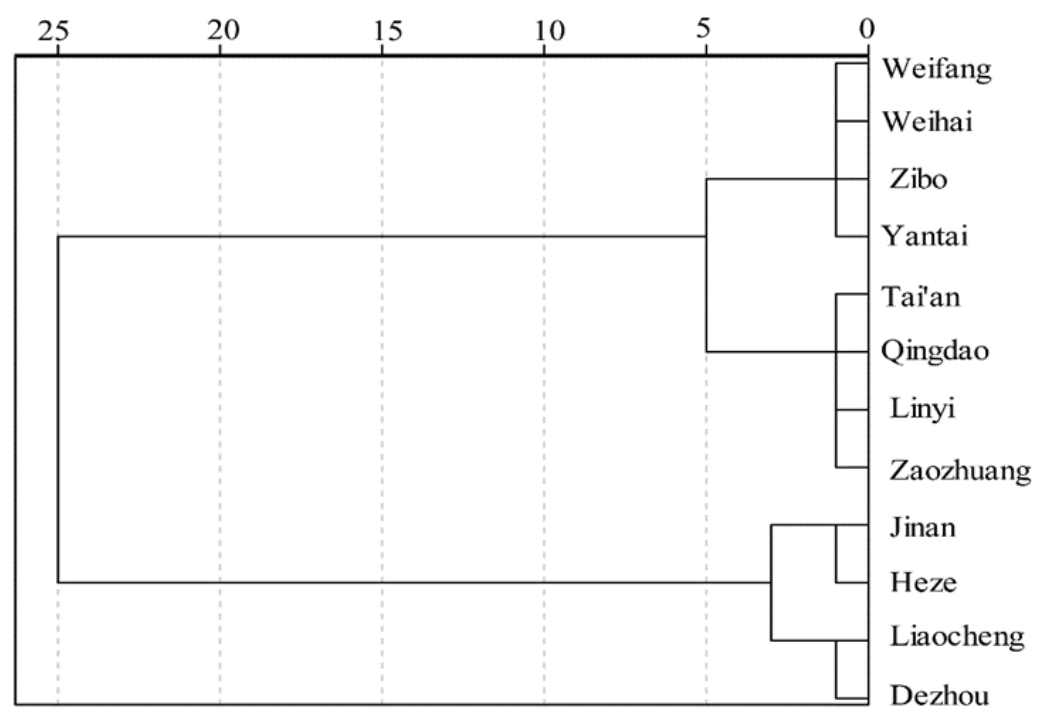

Figure 3. The cluster analysis of studied cities on the concentration of $\mathrm{Cr}$.

All the studied cities were polluted by $\mathrm{Pb}$ and $\mathrm{Cd}$, except for $\mathrm{Cd}$ in Jinan and Liaocheng (Figure 2). Though the mean contents of $\mathrm{Cd}$ and $\mathrm{Pb}$ were $0.162 \mathrm{mg} \cdot \mathrm{kg}^{-1}$ and $31.77 \mathrm{mg} \cdot \mathrm{kg}^{-1}$, respectively, the concentrations of $\mathrm{Cd}$ in Yantai and Linyi reached $0.8 \mathrm{mg} \cdot \mathrm{kg}^{-1}$ and $0.6 \mathrm{mg} \cdot \mathrm{kg}^{-1}$, and the maximal Pb content was up to $73.9 \mathrm{mg} \cdot \mathrm{kg}^{-1}$. The high standard deviation also suggested that point-source pollution commonly existed in these cities. Deposition of fly ash and irrigation can transfer exhaust gas and industrial waste to surrounding cropland soils directly, which would also lead to the high accumulation of heavy metals $[33,34]$. Thus, the point-source pollution and the similar spatial distributions of $\mathrm{Cd}$ and $\mathrm{Pb}$ may also attribute to the industrial activities $[35,36]$. Cluster analysis to the metals showed that $\mathrm{Cu}$, $\mathrm{Ni}, \mathrm{Pb}$ and $\mathrm{Cd}$ were gathered together, and then clustered the $\mathrm{Zn}$, while $\mathrm{Cr}$ had no significant association with other metals, indicating that sources of $\mathrm{Cr}$ may be very complex (Figure 4). Shan et al. [37] reported that $\mathrm{Cd}, \mathrm{Pb}$ and $\mathrm{Zn}$ in arable soils were mostly from the human factor, while Sun et al. [19] indicated the lithogenic origin of $\mathrm{Cr}$. The significantly higher contents of $\mathrm{Cr}$ in certain cities in this study suggest multiple sources from human activities, not domination by natural sources.

The dendrogram based on the mean Euclidean distance between groups

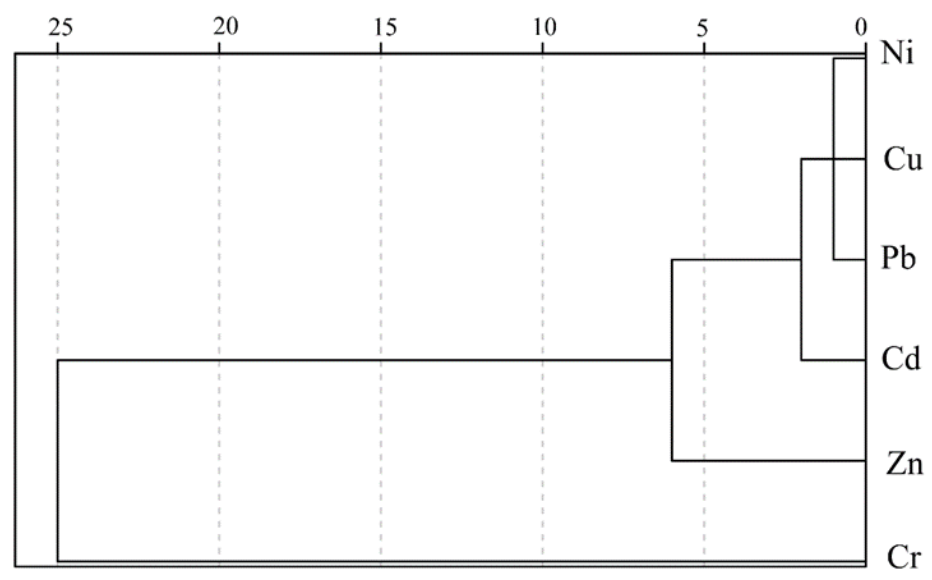

Figure 4. The cluster analysis of heavy metals among the studied cities. 


\subsection{The Distribution Pattern and Source Analysis of Heavy Metals in Different Soil Types}

Based on the second national soil census in China, brown soils, cinnamon soils and fluvo-aquic soils are the main soil types in Shandong Province [8]. The sampling area in this study involved 26 sites of cinnamon soils, 14 sites of fluvo-aquic soils and 15 sites of brown soils. Previous studies showed that heavy metals had different accumulating features in different soil types, as the soils had different values of organic matter, $\mathrm{pH}$, structural parameter, soil fertility, etc. [5,38,39]. In this study, concentrations of $\mathrm{Cr}$ in brown soils and cinnamon soils were $152.06 \mathrm{mg} \cdot \mathrm{kg}^{-1}$ and $149.38 \mathrm{mg} \cdot \mathrm{kg}^{-1}$, respectively, which were significantly higher than $\mathrm{Cr}$ in fluvo-aquic soils $\left(72.86 \mathrm{mg} \cdot \mathrm{kg}^{-1}\right.$; Figure 5 and Table 2). Moreover, the distribution pattern of $\mathrm{Cr}$ was the opposite of the $\mathrm{pH}$ in the soil types, which was significantly higher in fluvo-aquic soils (8.16) than in brown and cinnamon soils (6.59 \& 6.98). $\mathrm{Cr}$ is easily migratory and sensitive to $\mathrm{pH}$; thus, the significantly contradictory pattern suggested that the low $\mathrm{pH}$ was prone to the migration and bio-accumulation of $\mathrm{Cr}$ in the cropland [40,41]. In addition, Yang et al. [39] also suggested that yearly cultivation acidized the farmland, which was more vulnerable to metal accumulation. Furthermore, the higher contents of $\mathrm{Cr}$ in brown and cinnamon soils may also be attributed to the different soil fertilities—a soil's ability to supply and coordinate nutrients, moisture, air and heat for biological growth $[42,43]$.

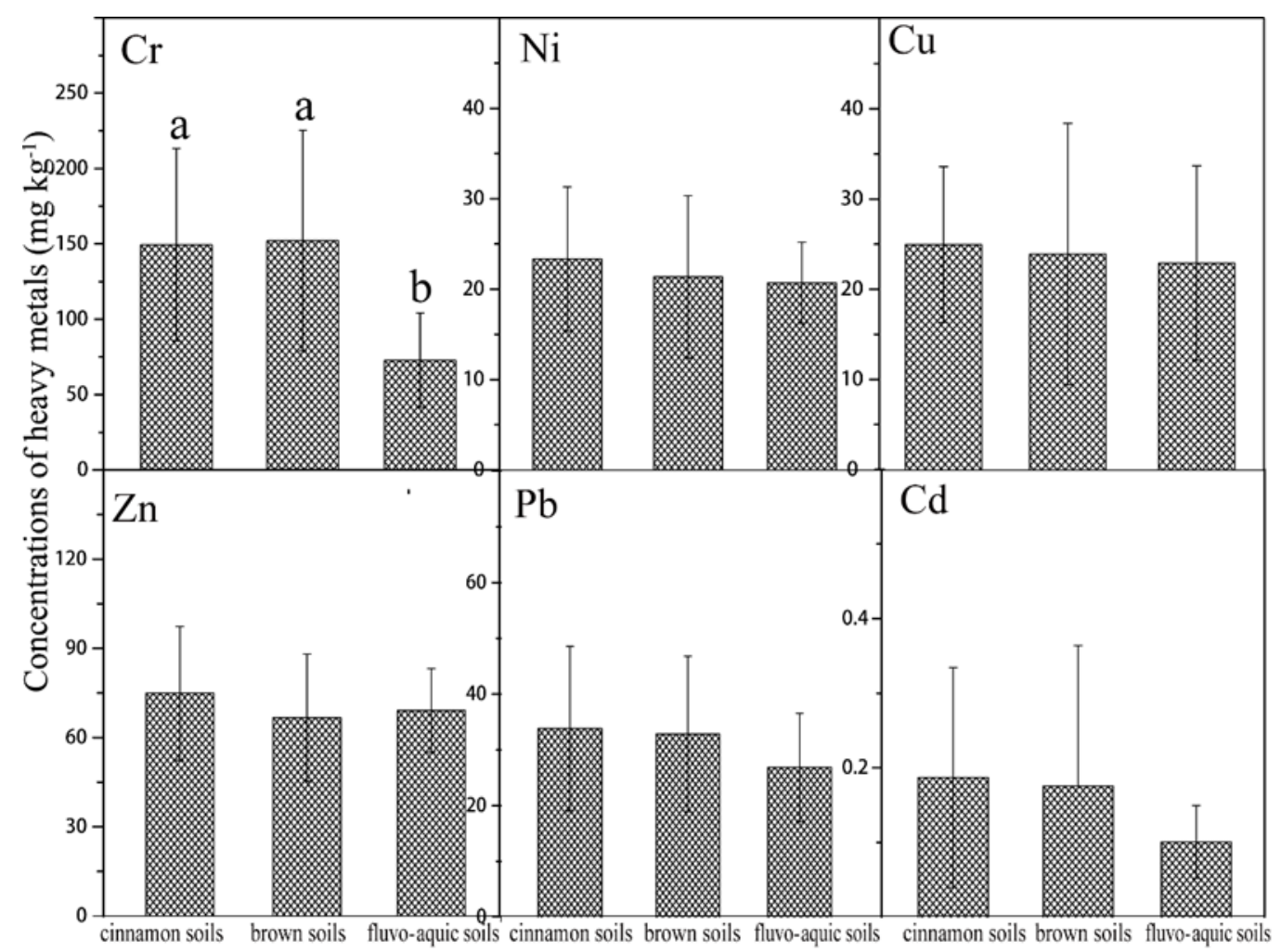

Figure 5. The distribution pattern of heavy metals in the three soil types. Bars sharing the same letter are not significant at $\alpha=0.05$ (Duncan test). 
Table 2. The concentrations of heavy metals in 2007 and $2017\left(\mathrm{mg} \cdot \mathrm{kg}^{-1}\right)$ [5].

\begin{tabular}{cccccccc}
\hline Soil types (2017) & $\mathrm{Cu}$ & $\mathrm{Pb}$ & $\mathrm{Cd}$ & $\mathrm{Cr}$ & $\mathrm{Ni}$ & $\mathrm{Zn}$ & $\mathrm{pH}$ \\
\hline Brown soil & 24.06 & 32.2 & 0.38 & 152.76 & 20.02 & 65.66 & 6.47 \\
Cinnamon soil & 26.39 & 33.21 & 0.25 & 150.2 & 24.12 & 80.65 & 6.98 \\
Fluvo-aquic soil & 22.36 & 28.04 & 0.14 & 80.64 & 21.36 & 68.43 & 8.10 \\
\hline Soil types (2007) & $\mathrm{Cu}$ & $\mathrm{Pb}$ & $\mathrm{Cd}$ & $\mathrm{Cr}$ & $\mathrm{Ni}$ & $\mathrm{Zn}$ & $\mathrm{pH}$ \\
\hline Brown soil & 73.87 & 99.05 & 0.08 & - & - & 85.93 & 6.70 \\
Cinnamon soil & 62.81 & 130.21 & 0.32 & - & - & 143.12 & 6.78 \\
Fluvo-aquic soil & 62.53 & 140.76 & 0.26 & - & - & 141.63 & 7.82 \\
\hline
\end{tabular}

The concentrations of $\mathrm{Cu}, \mathrm{Ni}, \mathrm{Cd}$ and $\mathrm{Pb}$ in the soil types were ordered as: cinnamon soils $>$ brown soils $>$ fluvo-aquic soils. The differences were not significant, indicating that the three soil types had no prominent and differentiated impact on the accumulation of these metals (Figure 5). The Pearson correlation analysis indicated that metals of $\mathrm{Cu}, \mathrm{Ni}$ and $\mathrm{Zn}$ were significantly related, and $\mathrm{Pb}$ and $\mathrm{Cd}$ were also significantly associated ( $p<0.01$; Table 3$)$. Du et al. [44] showed that discharge of $\mathrm{Cu}, \mathrm{Zn}$ and $\mathrm{Cd}$ were closely correlated with the industrial distribution. $\mathrm{Cr}, \mathrm{Ni}$ and $\mathrm{Pb}$ were from parent sources in Daye City, China, and some reports indicated that $\mathrm{Cd}$ and $\mathrm{Pb}$ were mostly enriched from industrial effluent, such as coal burning exhausts in Northeast China [19,37]. Thus, the spatial distribution of and contamination by heavy metals greatly differed among cropland areas of China, as did the metal correlations; this was confirmed in previous reports [12,45]. Crustal materials and anthropic pollution were the main sources. The metal contamination in farmland in China is mainly affected by local background values of heavy metals and human activities [45]. In this study, the contamination of $\mathrm{Cu}$, $\mathrm{Ni}$ and $\mathrm{Zn}$, and the accumulation of $\mathrm{Pb}$ and $\mathrm{Cd}$ in the cropland soils in Shandong Province were from different human activities and industrial producing. The contents of $\mathrm{Cr}$ were high and the correlation of $\mathrm{Cr}$ and other metals was not significant; thus it is suggested that sources of $\mathrm{Cr}$ may be various and complex. Thus, regulation and management on the discharge of industrial waste and on the agricultural practices need to be improved.

Table 3. The Pearson correlation analysis of heavy metals and economic indicators.

\begin{tabular}{|c|c|c|c|c|c|c|}
\hline Parameters & $\mathrm{Cr}$ & $\mathbf{N i}$ & $\mathrm{Cu}$ & $\mathrm{Zn}$ & $\mathrm{Cd}$ & $\mathbf{P b}$ \\
\hline $\mathrm{Cr}$ & 1 & & & & & \\
\hline $\mathrm{Ni}$ & -0.005 & 1 & & & & \\
\hline $\mathrm{Cu}$ & 0.104 & $0.313 *$ & 1 & & & \\
\hline $\mathrm{Zn}$ & $0.280 *$ & $0.292 *$ & $0.530 * *$ & 1 & & \\
\hline $\mathrm{Cd}$ & 0.058 & $0.320 *$ & 0.033 & 0.248 & 1 & \\
\hline $\mathrm{Pb}$ & 0.099 & 0.226 & -0.016 & 0.165 & $0.788 * *$ & 1 \\
\hline Gross product & 0.15 & -0.055 & -0.114 & $-0.284 *$ & -0.01 & 0.034 \\
\hline $\begin{array}{l}\text { The primary industrial } \\
\text { added value }\end{array}$ & 0.048 & -0.199 & -0.187 & $-0.307 *$ & 0.001 & -0.08 \\
\hline $\begin{array}{l}\text { The secondary industrial } \\
\text { added value }\end{array}$ & 0.035 & 0.007 & -0.08 & -0.242 & -0.024 & 0.032 \\
\hline The industrial added value & 0.179 & 0.021 & 0.305 & -0.187 & $0.520 *$ & 0.432 \\
\hline $\begin{array}{c}\text { The tertiary industrial } \\
\text { added value }\end{array}$ & 0.144 & 0.009 & -0.018 & -0.155 & 0.064 & 0.092 \\
\hline
\end{tabular}

*: significance on levels of $p<0.05 ; * *$ significance on levels of $p<0.01$.

\subsection{The Decadal Changes of Heavy Metals and Relations with Industrial Producing}

The mean value of $\mathrm{pH}$ in cinnamon soil and fluvo-aquic soil in 2017 was relatively higher than that in 2007, which suggested that yearly farming changed soil physical feature and grain yield, as $\mathrm{pH}$ was significantly and positively correlated with crop production [46]. The concentrations of $\mathrm{Cu}, \mathrm{Pb}$, 
Zn and Cd in 2017 were significantly decreased with respect to the accumulation in 2007, except for the insignificant change of $\mathrm{Cd}$ in brown soils (Table 2); the changes of $\mathrm{Cd}$ may attributable to the continuous input, leaching, migration and accumulation procedure of $\mathrm{Cd}$ in agricultural soils $[19,44]$. The significant reduction of above-mentioned metals from 2007 to 2017 suggests decreased human input, such as by decreasing the utilization of agrochemicals and the discharge of industrial waste and increasing the metal remediation and soil management $[47,48]$. Therefore, environmental management and ecological protection is vitally imperative for heavy metal remediation in agricultural soils.

The development of industry, agriculture, tourism and services brings about rapid growth of economy and living standards $[49,50]$. Meanwhile, the damage to ecological environment is also profound and lasting, which includes soil contamination around the industries, reduction of grain yield, destruction of natural habitat, etc. [51,52]. Thus, the relationship between economic indicators and heavy metals in agricultural soils should be researched. Factor analysis of heavy metals and economic indicators indicated three dominant factors, which explained $38.04 \%, 22.54 \%$ and $20.97 \%$ of the total factors, respectively (Table 4). The first factor mainly explained the $\mathrm{Cd}, \mathrm{Pb}$ and all economic indicators, indicating the close relation among $\mathrm{Cd}, \mathrm{Pb}$ and economic production. Factor 2 explained $\mathrm{Cr}, \mathrm{Ni}, \mathrm{Zn}$ and $\mathrm{Cu}$, which may suggest their common sources. Factor three explained the $\mathrm{Cr}$ and primary industrial added value, which indicated a certain industrial input. The remarkable impacts of economic production on $\mathrm{Cd}$ and $\mathrm{Pb}$ are in accordance with many previous studies $[53,54]$. In addition, concentrations of heavy metals presented certain relations with some economic indicators. Specifically, the primary industrial added value showed a significant and negative correlation with concentration of $\mathrm{Zn}$, while industrial added values indicated a significant and positive relationship with the contents of $\mathrm{Cd}$ (Table 3). That may suggest that industrial production aggravated the accumulation of $\mathrm{Cd}$, which can also be confirmed by the high accumulation of $\mathrm{Cd}$ in this study [36,37]. The closely related $\mathrm{Zn}$ and the primary industrial added value may attributable to the bio-accumulation, as primary industry was mainly involved in biological yield [55]. With the crop growth, Bhatti et al. [56] showed high bioaccumulation of $\mathrm{Zn}$ in the crops, while $\mathrm{Xu}$ et al. [37] indicated the high enrichment of $\mathrm{Cd}$ in the soils. Thus, the high primary industrial added value simultaneously boosted the bio-accumulation of $\mathrm{Zn}$ into aboveground vegetation and the enrichment of $\mathrm{Cd}$ into rhizosphere soils $[57,58]$.

Table 4. Factor analysis of heavy metals and economic indicators.

\begin{tabular}{cccc}
\hline Parameters & $\mathbf{1 ~ ( 3 8 . 0 4 \% )}$ & $\mathbf{2 ~ ( 2 2 . 5 4 \% )}$ & $\mathbf{3}(\mathbf{2 0 . 9 7 \% )}$ \\
\hline $\mathrm{Cr}$ & 0.497 & 0.67 & 0.441 \\
$\mathrm{Ni}$ & 0.185 & 0.569 & -0.47 \\
$\mathrm{Cu}$ & 0.606 & 0.7 & -0.053 \\
$\mathrm{Zn}$ & 0.087 & 0.826 & 0.384 \\
$\mathrm{Cd}$ & 0.801 & 0.03 & -0.358 \\
$\mathrm{~Pb}$ & 0.681 & 0.08 & -0.565 \\
The primary industrial added value & 0.615 & -0.341 & 0.508 \\
The secondary industrial added value & 0.885 & -0.349 & 0.098 \\
The industrial added value & 0.863 & -0.36 & 0.085 \\
The tertiary industrial added value & 0.913 & -0.202 & 0.071 \\
\hline
\end{tabular}

\section{Conclusions}

This study presented the spatial distribution patterns and contamination statuses of heavy metals in cropland soils of the twelve cities in Shandong Province, North China. Cropland soils of most studied cities are suffering from the contamination of $\mathrm{Cr}, \mathrm{Pb}$ and $\mathrm{Cd}$. Specifically, $\mathrm{Pb}$ and $\mathrm{Cd}$ had similar spatial distributions in those cities; the distribution of $\mathrm{Cr}$ may be affected by flowing orientation of basins. Concentrations of $\mathrm{Zn}$ and $\mathrm{Cu}$ were relatively high in Zibo and Weihai, whereas Weifang, Weihai, Yantai, and Zibo showed significantly high accumulation of $\mathrm{Cr}$. Moreover, contents of $\mathrm{Cr}$ in brown soils and cinnamon soils were significantly higher than in fluvo-aquic soils, while other metals showed no significant difference. This study also indicated that accumulation of $\mathrm{Pb}$ and $\mathrm{Cd}$ 
was mainly caused by economic activities, while $\mathrm{Cr}$ was prone to multi-sources. Contents of the metals were remarkably decreased with respect to their contents in 2007, except for Cd in brown soils. In conclusion, this study is significant to agricultural management on heavy metals contamination, and waste management and technology improvement are imperative to the cities that suffering from serious metal pollution.

Supplementary Materials: The following are available online at http://www.mdpi.com/2076-3417/10/6/1963/s1. Table S1: The longitude and latitude of the total sampling sites in Shandong Province. Table S2: The websites of cities' yearbooks in the statistical bureau. Table S3: The retrieved economic indicators from cities' yearbooks during 2017 (billion).

Author Contributions: Conceptualization, W.X. and J.C.; methodology, T.C.; software, W.X. and T.C.; validation, A.J., Y.P. and W.X.; formal analysis, Y.P.; investigation, W.X. and T.C.; writing — original draft preparation, W.X. and A.J.; writing - review and editing, J.C.; project administration, J.C.; funding acquisition, J.C. All authors have read and agreed to the published version of the manuscript.

Funding: This work was supported by the National Key Research and Development Program of China (grant numbers 2018YFD0800306-04 and 2018YFF0213404) and the National Natural Science Fund Committee, China (grant numbers 41877119 and 41471255).

Acknowledgments: We would like to thank Qingqing Cao for her investigation and supervision, and thank Huichao Yu for his investigation and data curation.

Conflicts of Interest: The authors declare no conflict of interest.

\section{References}

1. Meena, S.K.; Meena, V.S. Importance of Soil Microbes in Nutrient Use Efficiency and Sustainable Food Production. In Agriculturally Important Microbes for Sustainable Agriculture; Springer: Singapore, 2017; pp. 3-23.

2. Lorenz, K.; Lal, R. Chapter 9: Importance of soils of agroecosystems for climate change policy. In Carbon Sequestration in Agricultural Ecosystems 2018; Springer: Berlin/Heidelberg, Germany, 2018; pp. 357-386.

3. Trevors, J.T. Manage humans, not the environment. Water Air Soil Pollut. 2009, 205, 93-95. [CrossRef]

4. Pastor-Jáuregui, R.; Paniagua-López, M.; Martínez-Garzón, J.; Martín-Peinado, F.; Sierra-Aragón, M. Evolution of the Residual Pollution in Soils after Bioremediation Treatments. Appl. Sci. 2020, 10, 1006. [CrossRef]

5. Zhang, L. The research of the distribution characteristics of heavy metals and the environmental capacity of fundamental farmland in Shandong Province. Ph.D. Thesis, Shandong Normal University, Jinan, China, 2010.

6. Ping, J. Overview of researches on rural industrial development in China's new socialist countryside construction. Asian Agric. Res. 2012, 4, 5-9.

7. Huang, K.; Wang, J.; Bai, J.; Qiu, H. Domestic solid waste discharge and its determinants in rural China. China Agric. Econ. Rev. 2013, 5, 512-525. [CrossRef]

8. ZhiHua, T.; Liu, M.; Yi, L.; Guo, H.; Ouyang, T.; Yin, H.; Li, M. Source Apportionment and Health Risk Assessment of Heavy Metals in Eastern Guangdong Municipal Solid Waste. Appl. Sci. 2019, 9, 4755.

9. Oves, M.; Khan, M.S.; Zaidi, A.; Ahmad, E. Soil Contamination, Nutritive Value, and Human Health Risk Assessment of Heavy Metals: An Overview; Springer: Berlin/Heidelberg, Germany, 2012; pp. 1-27.

10. Wang, S.; Wu, W.; Liu, F.; Liao, R.; Hu, Y. Accumulation of heavy metals in soil-crop systems: A review for wheat and corn. Environ. Sci. Pollut. Res. 2017, 24, 15209-15225. [CrossRef]

11. Li, X.; Jiao, W.; Xiao, R.; Chen, W.; Chang, A. Soil pollution and site remediation policies in China: A review. Environ. Rev. 2015, 23, 263-274. [CrossRef]

12. Wong, S.C.; Li, X.-D.; Zhang, G.; Qi, S.H.; Min, Y.S. Heavy metals in agricultural soils of the Pearl River Delta, South China. Environ. Pollut. 2002, 119, 33-44. [CrossRef]

13. Cai, L.; Xu, Z.; Ren, M.; Guo, Q.; Hu, X.; Hu, G.; Wan, H.; Peng, P. Source identification of eight hazardous heavy metals in agricultural soils of Huizhou, Guangdong Province, China. Ecotoxicol. Environ. Saf. 2012, 78, 2-8. [CrossRef]

14. Wei, B.; Yang, L. A review of heavy metal contaminations in urban soils, urban road dusts and agricultural soils from China. Microchem. J. 2010, 94, 99-107. [CrossRef] 
15. Lu, A.; Wang, J.; Qin, X.; Wang, K.; Han, P.; Zhang, S. Multivariate and geostatistical analyses of the spatial distribution and origin of heavy metals in the agricultural soils in Shunyi, Beijing, China. Sci. Total. Environ. 2012, 425, 66-74. [CrossRef] [PubMed]

16. Meng, F.; Liu, M.; Shi, T.-G. Evaluation on environmental quality of heavy metals in agricultural soils of Shanghai. Huan Jing Ke Xue 2008, 29, 428. [PubMed]

17. Veeresh, H.; Tripathy, S.; Chaudhuri, D.; Hart, B.R.; Powell, M. Competitive adsorption behavior of selected heavy metals in three soil types of India amended with fly ash and sewage sludge. Environ. Earth Sci. 2003, 44, 363-370. [CrossRef]

18. Lijie, J. Adsorption properties of heavy metals in different type soils. Ecol Environ. 2008, 17, 245-248.

19. Sun, C.; Liu, J.; Wang, Y.; Sun, L.; Yu, H. Multivariate and geostatistical analyses of the spatial distribution and sources of heavy metals in agricultural soil in Dehui, Northeast China. Chemosphere 2013, 92, 517-523. [CrossRef] [PubMed]

20. Gan, Y.; Miao, Y.; Wang, L.-H.; Yang, G.; Li, Y.C.; Wang, W.; Dai, J. Source Contribution Analysis and Collaborative Assessment of Heavy Metals in Vegetable-Growing Soils. J. Agric. Food Chem. 2018, 66, 10943-10951. [CrossRef]

21. Heng, J.Z.; Yao, L.; Gang, S.Y.; Fan, L.; Fa, C.C.; Feng, T.W.; Hong, Q.T. Speciation, distribution and sources of heavy metals in agricultural soils from the mining area of Longjiao Mountain in Daye City. J. Agro-Environ. Sci. 2017, 36, 264-271.

22. He, F.; Wang, T.; Gu, L.; Li, T.; Jiang, W.; Shao, H. An Integrated Use of Topography with RSI in Gully Mapping, Shandong Peninsula, China. Sci. World J. 2014, 2014, 1-9. [CrossRef]

23. Wang, M.; Jiang, L.H.; Liu, Z.H.; Zheng, F.L.; Dong, J. Impacts of petroleum pollutants on microbial population and enzyme activity in three different types of soils in Shandong Province. Acta Pedol. Sin. 2010, 47, 341-346.

24. Zhen, L. The national census for soil erosion and dynamic analysis in China. Int. Soil Water Conserv. Res. 2013, 1, 12-18. [CrossRef]

25. Song, H.; Sun, Z. Temporal variations and bioaccumulation of heavy metals in different Suaeda salsa marshes of the Yellow River estuary, China. Environ. Sci. Pollut. Res. 2014, 21, 14174-14187. [CrossRef] [PubMed]

26. Albanese, S.; Sadeghi, M.; De Vivo, B.; Lima, A.; Cicchella, D.; Dinelli, E. Nickel, cobalt, chromium and copper in agricultural and grazing land soils of Europe. EGU General Assemb. 2014, 16, 13544.

27. Zhang, L.; Qin, Y.-W.; Ma, Y.-Q.; Zhao, Y.-M.; Shi, Y. Spatial distribution and pollution assessment of heavy metals in the tidal reach and its adjacent sea estuary of Daliaohe area, China. Huan Jing Ke Xue 2014, 35, 3336. [PubMed]

28. Kazakis, N.; Kantiranis, N.; Kalaitzidou, K.; Kaprara, E.; Mitrakas, M.; Frei, R.; Vargemezis, G.; Vogiatzis, D.; Zouboulis, A.; Filippidis, A. Environmentally available hexavalent chromium in soils and sediments impacted by dispersed fly ash in Sarigkiol basin (Northern Greece). Environ. Pollut. 2018, 235, 632-641. [CrossRef]

29. Wang, S.; Nan, Z.; Liu, X.; Li, Y.; Qin, S.; Ding, H. Accumulation and bioavailability of copper and nickel in wheat plants grown in contaminated soils from the oasis, northwest China. Geoderma 2009, 152, 290-295. [CrossRef]

30. Lin, Z. Evaluation and Countermeasures on sustainable development of nickel resources in China. IOP Conf. Ser. Earth Environ. Sci. 2017, 81, 12113. [CrossRef]

31. Lin, Y.; Han, P.; Huang, Y.; Yuan, G.-L.; Guo, J.-X.; Li, J. Source identification of potentially hazardous elements and their relationships with soil properties in agricultural soil of the Pinggu district of Beijing, China: Multivariate statistical analysis and redundancy analysis. J. Geochem. Explor. 2017, 173, 110-118. [CrossRef]

32. Luo, X.-S.; Zhou, D.; Liu, X.-H.; Wang, Y.-J. Solid/solution partitioning and speciation of heavy metals in the contaminated agricultural soils around a copper mine in eastern Nanjing city, China. J. Hazard. Mater. 2006, 131, 19-27. [CrossRef]

33. Sharma, A.P.; Tripathi, B.D. Magnetic mapping of fly-ash pollution and heavy metals from soil samples around a point source in a dry tropical environment. Environ. Monit. Assess. 2007, 138, 31-39. [CrossRef]

34. Qi, X.-B. Soil heavy metal residue under different treated waste-water irrigation technique and management. Chin. J. Eco-Agric. 2008, 16, 839-842. [CrossRef]

35. Cao, Q.; Liu, B.; Ren, Z.; Xiao, H.; Cheng, J.; Xue, W. Temporal Distribution Characteristic and Risk Analysis of Heavy Metals in Greenhouse Vegetable Soils. Pol. J. Environ. Stud. 2020, 29, 111318. [CrossRef] 
36. Gan, Y.; Wang, L.; Yang, G.; Dai, J.; Wang, R.; Wang, W. Multiple factors impact the contents of heavy metals in vegetables in high natural background area of China. Chemosphere 2017, 184, 1388-1395. [CrossRef] [PubMed]

37. Shan, Y.; Tysklind, M.; Hao, F.; Ouyang, W.; Chen, S.; Lin, C. Identification of sources of heavy metals in agricultural soils using multivariate analysis and GIS. J. Soils Sediments 2013, 13, 720-729. [CrossRef]

38. Yang, T.; Liu, Q.; Zeng, Q.; Chan, L. Relationship between magnetic properties and heavy metals of urban soils with different soil types and environmental settings: Implications for magnetic mapping. Environ. Earth Sci. 2011, 66, 409-420. [CrossRef]

39. Yang, L.; Huang, B.; Hu, W.; Chen, Y.; Mao, M.; Yao, L. The impact of greenhouse vegetable farming duration and soil types on phytoavailability of heavy metals and their health risk in eastern China. Chemosphere 2014, 103, 121-130. [CrossRef]

40. Borah, P.; Singh, P.; Rangan, L.; Karak, T.; Mitra, S. Mobility, bioavailability and ecological risk assessment of cadmium and chromium in soils contaminated by paper mill wastes. Groundw. Sustain. Dev. 2018, 6, 189-199. [CrossRef]

41. Chen, H.; Arocena, J.M.; Li, J.; Thring, R.W.; Zhou, J. Assessments of chromium (and other metals) in vegetables and potential bio-accumulations in humans living in areas affected by tannery wastes. Chemosphere 2014, 112, 412-419. [CrossRef]

42. Wang, Y.; Xu, Y.; Li, D.; Tang, B.; Man, S.; Jia, Y.; Xu, H. Vermicompost and biochar as bio-conditioners to immobilize heavy metal and improve soil fertility on cadmium contaminated soil under acid rain stress. Sci. Total. Environ. 2018, 621, 1057-1065. [CrossRef]

43. Latare, A.; Kumar, O.; Singh, S.; Gupta, A. Direct and residual effect of sewage sludge on yield, heavy metals content and soil fertility under rice-wheat system. Ecol. Eng. 2014, 69, 17-24. [CrossRef]

44. Du, P.; Xie, Y.; Wang, S.; Zhao, H.; Zhang, Z.; Wu, B.; Li, F. Potential sources of and ecological risks from heavy metals in agricultural soils, Daye City, China. Environ. Sci. Pollut. Res. 2014, 22, 3498-3507. [CrossRef]

45. Xie, S.; Yang, F.; Feng, H.; Wei, C.; Wu, F. Assessment of Potential Heavy Metal Contamination in the Peri-urban Agricultural Soils of 31 Provincial Capital Cities in China. Environ. Manag. 2019, 64, 366-380. [CrossRef] [PubMed]

46. Kemmitt, S.J.; Wright, D.; Goulding, K.; Jones, D.L. pH regulation of carbon and nitrogen dynamics in two agricultural soils. Soil Boil. Biochem. 2006, 38, 898-911. [CrossRef]

47. Schipper, P.; Bonten, L.; Plette, A.; Moolenaar, S. Measures to diminish leaching of heavy metals to surface waters from agricultural soils. Desalination 2008, 226, 89-96. [CrossRef]

48. Xu, Y.; Xu, Y.; Xu, Y.; Qin, X.; Huang, Q.; Wang, L.; Sun, Y. Remediation of Heavy Metal-Polluted Agricultural Soils Using Clay Minerals: A Review. Pedosphere 2017, 27, 193-204. [CrossRef]

49. Zhao, N.; Currit, N.; Samson, E. Net primary production and gross domestic product in China derived from satellite imagery. Ecol. Econ. 2011, 70, 921-928. [CrossRef]

50. Li, T.; Ding, Y. Spatial disparity dynamics of ecosystem service values and GDP in Shaanxi Province, China in the last 30 years. PLoS ONE 2017, 12, e0174562. [CrossRef]

51. Vu, T.; Lin, C.; Yeh, G.; Villanueva, M.C. Bioaccumulation and potential sources of heavy metal contamination in fish species in Taiwan: Assessment and possible human health implications. Environ. Sci. Pollut. Res. 2017, 24, 19422-19434. [CrossRef]

52. Bhatti, S.S.; Sambyal, V.; Nagpal, A. Analysis of Genotoxicity of Agricultural Soils and Metal (Fe, Mn, and Zn) Accumulation in Crops. Int. J. Environ. Res. 2018, 12, 439-449. [CrossRef]

53. Jalali, M.; Khanlari, Z.V. Environmental contamination of $\mathrm{Zn}, \mathrm{Cd}, \mathrm{Ni}, \mathrm{Cu}$, and $\mathrm{Pb}$ from industrial areas in Hamadan Province, western Iran. Environ. Earth Sci. 2007, 55, 1537-1543. [CrossRef]

54. Micha, W.; Waldemar, S.; Laura, B. Trace metal (Cd, Cu, Pb, Zn) fractionation in urban-industrial soils of Ust-Kamenogorsk (Oskemen), Kazakhstan-Implications for the assessment of environmental quality. Environ Monit. Assess. 2018, 190, 362.

55. Clement, K. Economic development and environmental gain: European environmental integration and regional competitiveness. Math Gazette 2000, 446, 283-284.

56. Paraskevas, D.; Voorde, A.V.D.; Kellens, K.; Dewulf, W.; Duflou, J.R. Current status, future expectations and mitigation potential scenarios for China's Primary Aluminium Industry. Procedia Cirp. 2016, 48, $295-300$. [CrossRef] 
57. Biswas, J.K.; Banerjee, A.; Sarkar, B.; Sarkar, D.; Sarkar, S.K.; Rai, M.; Vithanage, M. Exploration of an Extracellular Polymeric Substance from Earthworm Gut Bacterium (Bacillus licheniformis) for Bioflocculation and Heavy Metal Removal Potential. Appl. Sci. 2020, 10, 349. [CrossRef]

58. Hwang, S.; Her, Y.; Jun, S.; Song, J.-H.; Lee, G.; Kang, M.S. Characteristics of Arsenic Leached from Sediments: Agricultural Implications of Abandoned Mines. Appl. Sci. 2019, 9, 4628. [CrossRef]

(C) 2020 by the authors. Licensee MDPI, Basel, Switzerland. This article is an open access article distributed under the terms and conditions of the Creative Commons Attribution (CC BY) license (http://creativecommons.org/licenses/by/4.0/). 